\title{
Uji Ketahanan Bakteri Dehalogenasi pada Subtrat Herbisida KMCPA Formula.
}

\author{
Nurhayati \\ Laboratorium Mikrobiogenetika,Jurusan Biologi FMIPA Undip
}

\begin{abstract}
Absrak
Herbisida 2-metil-4-klor fenoksi asetat formula (KMCPA) merupakan salah satu jenis herbisida yang toksik dan tahan di tanah sampai 1 tahun. Stabilitas dan toksisitas KMCPA mengakibatkan senyawa ini berpotensi sebagai polutan. Polutan yang masuk ke tanah dan badan air sangat berbahaya bagi lingkungan. Mikrobia memiliki serangkaian enzim yang dapat mengakatalisis senyawa toksik ini. Penelitian ini dilakukan untuk mendapatkan isolat bakteri dehalogenasi dan untuk menguji ketahanan isolat dalam menggunakan KMCPA sebagai sumber karbon dengan variasi konsentrasi $1,1 \mathrm{~g} / \mathrm{L} ; 2,2 \mathrm{~g} / \mathrm{L} ; 3,3 \mathrm{~g} / \mathrm{L}$. Parameter yang diamati adalah uji kualitatif pada tahap skrining menggunakan medium minimal Solution base salt (SBS) dan indikator BTB dan pengamatan kurva pertumbuhan berdasarkan pertambahan biomassa yanag diukur dengan spektrofotometer pada $\lambda=600 \mathrm{~nm}$. Isolat yang tahan sampai dosis 3 kali aplikasi di lapangan ( 3,3 g/L) adalah isolat M, sedangkan isolat P1, P2, P3; B1, B2, B3 tidak tahan terhadap KMCPA dengan dosis 3 kali dosis aplikasi di lapangan tidak dilanjutkan . Isolat M diharapkan dapat digunakan sebagai agen pembersih lingkungan namun konsentrasi KMCPA yang digunakan sebaiknya tidak lebih dari $1,1 \mathrm{~g} / \mathrm{L}$.
\end{abstract}

Kata Kunci: Dehalogenasi, 2-metil-4-klor-fenoksi asam asetat (KMCPA), dehalogenase.

\section{PENDAHULUAN}

Studi mengenai biodegradasi komponen terhalogenasi dimulai pada awal abad ke-20 terkait dengan banyaknya limbah dari senyawa terhalogenasi. Senyawa terhalogenasi bersifat toksik ( Slater; J.H; Bull, A.T.; \& D.J. Hardman; 1995 ).Senyawa terhalogenasi berpotensi menyebabkan keracunan, teratogenik serta karsinogenik. Metabolit yang dihasilkan dari hasil biodegradasi senyawa organoklorin sering bersifat toksik karena menghambat reaksi-reaksi kunci di metabolisme sel. Salah satu senyawa intermediat yang toksik adalah floroasetat yang potensial sebagai inhibitor pada siklus asam trikarboksilat, karena senyawa ini dapat menghambat akonitase yang berperan di siklus asam sitrat (TCA) ( Peters, 1952 ).

Dari hasil penelitian yang dilakukan oleh beberapa peneliti diketahui bahwa sejumlah mikrobia berhasil diisolasi dan diseleksi berdasarkan kemampuan tumbuh pada komponen terhalogenasi misalnya genus Pseudomonas, Alcaligenes, Rhodococcus, Hyphomicrobium ( Slater, 1994 ). Beberapa mikrobia yang memiliki kemampuan tumbuh dan melakukan biodegradasi senyawa terhalogenasi karena memiliki enzim dehalogenase.
Enzim yang mengkatalisis reaksi dehalogenasi disebut dehalogenase ( Jensen, 1960 dalam Slater, et al 1995). Mekanisme pemutusan halogen dari komponen aromatik meliputi berlangsung secara oksidatif, hidrolitik dan reduktif. Mekanisme biodegradasi pestisida oleh mikrobia secara oksidatif yaitu proses terlepasnya halogen dari senyawa aromatik terhalogenasi dengan melibatkan enzim dan oksigen. Dehalogenasi hidrolitik yaitu mekanisme biodegradasi senyawa terhalogenasi dengan melibatkan enzim dan hidrogen sedangkan proses dehalogenasi reduktif adalah proses terlepasnya halogen yang merupakan gugus penentu toksisitas dari senyawa terhalogenasi dengan melibatkan enzim dan proses reaksi reduksi. Pada tabel 1 berikut ini adalah mekanisme berbagai macam reaksi dehalogenasi yang dikatalisis oleh enzim mikrobia. 
Tabel 1. Macam Pestisida, mekanisme biodegradasi pestisida ( Commandeur \& Parsons, 1994 ).

\begin{tabular}{ll}
\hline Pestisida & Mikrobia-Mekasnisme \\
\hline Fenol terhalogenasi & Bakteri Aerobik \\
chlorofenol & Kapang \\
Halofenol & Bakteri anaerob \\
Fenolik terklorinasi & Biotransformasi oleh Bakteri \\
Herbisida fenoksialkanoat terklorinasi & Bakteri Aerob \\
Klorofenol asam asetat & Kapang \\
Fenoksi asam asetat & Bakteri Anaerob \\
Halobenzoat & Bakteri aerob \\
Asam halobensoat & Bakteri anaerob \\
Halobensen & Bakteri Aerob \\
Halobensen & Bakteri anaerob \\
Fenilamid dan anilin & Hidrolisis \\
Anilin terhalogenasi & Transformasi aerob dan degradasi \\
Fenilamid dan anilin & Dehalogenasi anaerob. \\
&
\end{tabular}

Pada proses dehalogenase oksidatif gugus halogen digantikan oleh oksigen, halogen dilepas secara spontan setelah cincin aromatik putus, dehalogenase oksidatif seringkali diikuti oleh proses dehalogenasi yang melibatkan aktivitas oksigenase ( Commandeur \& Parsons, 1994 ).

Dehalogenase hidrolitik mengkatalisis lepasnya halogen dari senyawa terhalogenasi dan digantikan dengan air, baik dalam kondisi aerob dan anaerob. Beberapa mikrobia yang memiliki aktivitas dehalogenase hidrolitik adalah Pseudomonas sp strain CBS3 ( Loffler et al.; 1992 ) dan Arthrobacter sp strain SU (Schmitz et al. 1992 ). Pada proses dehalogenasi reduktif senyawa aromatik terhalogenasi sebagai senyawa utama dalam pestisida dalam keadaan anaerob berfungsi sebagai aseptor elektron terakhir. Mikrobia yang memiliki dehalogenase reduktif adalah Desulfominile tiedje.

Mekanisme putusnya halogen, khususnya florin dan klorin dari molekul organik mengurangi efek inhibitor dan sumber karbon yang ada dapat digunakan sebagaai sumber $\mathrm{C}$ alternatif dan energi untuk pertumbuhan (Slater; et al 1995).

Dari hasil penelitian diketahui bahwa herbisida 2,4-diklorofenoksiasetat (2,4-D) dapat segera terdegradasi di tanah, sementara 2,4,5Trikloroasam asetat (2,4,5-T) dan 4-klor-2metilfenoksi asetat (MCPA) lebih perisiten atau tahan. Degradasi MCPA oleh bakteri di dalam tanah telah diteliti oleh berbagai peneliti dengan mengamati kemampuan melepas klorida dari subtitusi klorida pada subtrat utama senyawa organoklorin baik dari pestisida, fungisida dan hervbisida (Loos, M.A.; 1975 ). Pseudomonas sp. merupakan salah satu bakteri yang dapat menggunakan MCPA sebagai sumber karbon satusatunya ( Evans, et. al.; 1971 ), mikrobia lain yang dapat menggunakan herbisida MCPA sebagai sumber karbon untuk pertumbuhannya adalah Alcaligenes, Azotobacter, Pseudomonas, Acinetobacter, Xanthobacter dan Flavobacterium ( Balajee \& Mahadevan, 1990 ).

Biodegradasi MCPA oleh mikrobia diawali dengan pemutusan secara oksidatif ikatan eter menghasilkan fenol. Reaksi berikutnya adalah terjadinya hidrolisasi katekol diikuti dengan pemutusan cincin secara ortho pada isolat Alcaligenes eutrophus JMP 134. Beberapa strain mikrobia memiliki plasmid yang memiliki gen mengkode berbagai macam enzim yang dapat mendegradasi MCPA, yang merupakan mikrobia dengan plasmid "broad range" dan dapat ditransfer secara bebas antar mikroorganisme di dalam tanah ( Don, \& Pemberton, 1981). Dari berbagai penelitian diketahui bahwa mikrobia memiliki serangkaian enzim kunci dari yang memiliki organisasi dan regulasi gen yang dapat mendegradasi haloaromatik.

Adanya limbah terhalogenasi yang berbahaya dan melimpahnya mikrobia yang memiliki kemampuan untuk mengkatialisis proses biodegradasi senyawa terhalogenasi maka dari penelitian ini diharapkan didapatkan mikrobia yang dapat digunakan sebagai agen pembersih tanah dan air yang terkontaminasi komponen aromatik terhalogenasi. Dari penelitian ini juga akan dianalisis beberapa mikrobia khususnya bakteri dalam berbagai konsentrasi KMCPA untuk menentukan ketahanan tumbuh pada KMCPA berdasarkan kemampuan tumbuh bakteri sampai pada 3 kali dosis aplikasi lapangan.

\section{BAHAN DAN METODE Mikrobia}

Bakteri isolat $\mathrm{M}, \mathrm{P} 1, \mathrm{P} 2, \mathrm{P} 3$; B1, B2, B3 diisolasi dari sampel tanah sekitar hulu Kaliboyong, Kaliurang, Yogayakarta ( Prof. Dr. Endang S, MSc dari Biologi-UGM) 


\section{Bahan Media Uji Ketahanan Bakteri}

Media subtrat KMCPA formula dengan berbagai konsentrasi $(1,1, \mathrm{~g} / \mathrm{l} ; 2,2 \mathrm{~g} / \mathrm{l} ; 3,3 \mathrm{~g} / \mathrm{l})$. Komposisi medium cair basal garam Solution Base Salt (SBS) yang mengandung (g/l) : 1,5-K2HPO4; 1,0-KH2PO4; 0,5-(NH4)2SO4; 0,2-MgSO4.7H2O dan mineral ditambah $10 \mathrm{~mL}$ mengandung $(\mathrm{g} / \mathrm{L})$ : 12-Na2EDTA.2H2O; 2-NaOH; 0,4-ZnSO4.2H2O; 1-CuSO4; 10-Na2SO4; 2-FeSO4.7H2O; 0,1$\mathrm{Na} 2 \mathrm{MoO} 4.2 \mathrm{H} 2 \mathrm{O}$ dan $0,5 \mathrm{~mL} \mathrm{H} 2 \mathrm{SO} 4$ pekat, yeast extract $0,05 \%$.

\section{Isolasi dan Pemeliharaan bakteri dehalogenasi}

Isolasi bakteri dehalogenasi melalui teknik kultur diperkaya menggunakan medium KMCPA formula sebagai sumber C. Satu gram sampel tanah diinokulasikan ke dalam $100 \mathrm{~mL}$ SBS pada $250 \mathrm{~mL}$ labu erlenmeyer ( Slater et al, 1979 ) ditambah $1,1 \mathrm{~g} / \mathrm{L}$ KMCPA formula $(0,5 \mathrm{~g} \mathrm{C} / \mathrm{L})$ dan ditambah $0,05 \%$ (w/v) yeast extract ( Liu et al, 1995 ). Medium cair diinokulasi dengan sampel tanah diinkubasikan dalam inkubator shaker ( 150 rpm ) pada suhu $37^{\circ} \mathrm{C}$ selama 3 hari. Pertumbuhan dipantau dengan mengukur pelepasan klor ke dalam medium dengan chlorocounter. Setelah ion klorida optimal ( mencapai $40 \%: 66,22 \mathrm{mg} / \mathrm{L}$ ) dilakukan subkultur dengan menggunakan medium yang sama dengan kadar KMCPA formula setara dengan $0,5 \mathrm{~g} \mathrm{C} / 1(1,1 \mathrm{~g} / \mathrm{L})$. Setelah tiga kali subkultur bakteri diisolasi melalui seri pengenceran dan ditumbuhkan pada medium padat SBS yang mengandung subtrat yang sama untuk subkultur. Medium diinkubasi pada suhu $37^{\circ} \mathrm{C}$ selama 4 hari.

Seleksi bakteri dehalogenasi ( Soetarato, 1997; Strotmann \& Roschenthaler, 1987).

Bakteri yang diperoleh dari hasil isolasi diseleksi berdasarkan kemampuan tumbuh dan melepas ion klorida ke dalam medium padat. Medium pertumbuhan bakteri ditambah dengan indikator Bromothymol Blue (BTB). Medium padat adalah medium basal SBA (Slater et al, 1979) ditambah agar $1,5 \%$ (w/v) dan $0,5 \mathrm{ml} \mathrm{BTB}$ $0,4 \%$ (w/v) (Strotman \& Roschenthaler, 1987). Sebagai sumber C digunakan KMCPA formula $0,11 \mathrm{~g} / 100 \mathrm{~mL}$ ditambah $0,05 \%$ yeast extract $(\mathrm{w} / \mathrm{v})$. Medium diinkubasi selama 3 hari pada suhu $37^{\circ}$ C sampai terlihat pertumbuhan koloni dan perubahan warna medium. Aktivitas dehalogenase ditandai dengan perubahan warna medium dari biru menjadi hijau atau kekuningan.

\section{HASIL DAN PEMBAHASAN}

Uji ketahanan bakteri dehalogenasi pada subtrat utama herbisida KMCPA formula

Hasil subkultur dari sampel tanah 3 kali berturut-turut pada medium padat SBS yang ditambah dengan subtrat utama herbisida KMCPA formula dengan konsentrasi 1,1 g / L didapatkan 7 isolat yaitu isolat $\mathrm{M}, \mathrm{P} 1, \mathrm{P} 2, \mathrm{P} 3, \mathrm{~B} 1, \mathrm{~B} 2, \mathrm{~B} 3$. Kemampuan isolat tumbuh pada medium subkultur mengindikasikan bahwa mikrobia memiliki kemampuan menggunakan herbisida KMCPA formula sebagai sumber karbon. Kemampuan menggunakan KMCPA formula sebagai sumber karbon karena bakteri tersebut memiliki enzim dehalogenase (Slater, 1994). Enzim dehalogenase adalah enzim yang mengkatalisis pelepasan ion klor yang toksik. Putusnya ion klor dan cincin aromatik dari subtrat KMCPA formula akan mempermudah bakteri menggunakan sumber karbon untuk dikatabolisme menjadi sebagai sumber energi bagi sel. Bakteri hasil subkultur sebanyak 7 isolat diatas kemudian dilakukan uji ketahanan pertumbuhan dengan konsentrasi KMCPA formula $1,1 \mathrm{~g} / \mathrm{L} ; 2,2 \mathrm{~g} / \mathrm{L}$ dan 3,3 g / L. Bakteri yang memiliki kemampuan tumbuh pada konsentrasi 3,3 $\mathrm{g} / \mathrm{L}$ merupakan dosis 3 kali aplikasi herbisida di lapangan akan digunakan lebih lanjut untuk analisis pertumbuhan mikrobia. Isolat $\mathrm{M}$ adalah satu-satunya bakteri yang memiliki pertumbuhan pada dosis 3,3 g/L KMCPA sedangkan isolat P1, P2, P3, B1, B2, B3 tidak dapat tumbuh pada konsentrasi KMCPA 3,3 g/L seperti tertera di Tabel 2. 
Tabel 2. Uji ketahanan bakteri dehalogenasi pada subtrat utama herbisida KMCPA formula

\begin{tabular}{l|l|l|l} 
Isolat & $\begin{array}{l}\text { Herbisida } \\
\text { KMCPA }\end{array}$ & $\begin{array}{l}\text { Herbisida } \\
\text { KMCPA }\end{array}$ & $\begin{array}{l}\text { Herbisida } \\
\text { KMCPA }\end{array}$ \\
& Formula & Formula & Formula \\
& $\mathbf{1 , 1}$ g / L & $\mathbf{2 , 2}$ g / L & $\mathbf{3 , 3}$ g / L \\
\hline Isolat M & Tumbuh & Tumbuh & Tumbuh \\
Isolat P1 & Tumbuh & Tumbuh & Tidak tumbuh \\
Isolat P2 & Tumbuh & Tumbuh & Tidak Tumbuh \\
Isolat P3 & Tumbuh & Tumbuh & Tidak Tumbuh \\
Isolat B1 & Tumbuh & Tumbuh & Tidak Tumbuh \\
Isolat B2 & Tumbuh & Tumbuh & Tidak Tumbuh \\
Isolat B3 & Tumbuh & Tumbuh & Tidak Tumbuh \\
& & &
\end{tabular}

Pada konsentrasi herbisida KMCPA formula $1,1 \mathrm{~g} / \mathrm{L}$ yang merupakan dosis aplikasi di lapangan seluruh mikrobia dapat tumbuh haal ini mengindikasikan bahwa kosentrasi $1,1 \mathrm{~g} / \mathrm{L}$ merupakan konsentrasi yang aman bagi isolat $\mathrm{M}$, P1, P2, P3, B1, B2, B3. Demikian juga pada konsentrasi KMCPA formula 2,2 g / $\mathrm{L}$ yang merupakan 2 kali dosis aplikasi di lapangan dapat digunakan sebagai sumber $\mathrm{C}$ untuk pertumbuhan dan sumber bagi isolat $\mathrm{M}, \mathrm{P} 1, \mathrm{P} 2, \mathrm{P} 3, \mathrm{P} 4, \mathrm{~B} 1, \mathrm{~B} 2$, B3. Namun pada konsentrasi KMCPA formula 3,3 g / L ( 3 kali dosis aplikasi di lapangan ) menyebabkan isolat P1, P2, P3, P4, B1, B2, B3 tidak tumbuh sedangkan isolat $\mathrm{M}$ merupakan isolat satu-satunya isolat yang memiliki kemampuan tumbuh hal ini mengindikasikan bahwa isolat $\mathrm{M}$ merupakan isolat yang memiliki ketahanan paling baik diantara 7 isolat. Isolat $M$ selanjutnya digunakan untuk penelitian dan dinalisis pertumbuhannya dengan 3 macam konsentrasi KMCPA formula yaitu 1,1 g / L; 2,2 g / L; 3,3 g / L.

Pertumbuhan Isolat Bakteri M pada Berbagai Macam Konsentrasi Herbisida KMCPA

Isolat bakteri $\mathrm{M}$ dianalisis kemampuan pertumbuhannya pada medium yang mengandung herbisida KMCPA formula dengan 3 macam konsentrasi konsentrasi 1,1 g / L; 2,2 g / L; 3,3 g / L. Dari hasil penelitian diketahui bahwa isolat $\mathrm{M}$ dapat tumbuh pada KMCPA formula sampai dengan 3 dosis aplikasi di lapangan $\mathrm{Hal}$ ini mengindikasikan bahwa bakteri isolat $\mathrm{M}$ memiliki kemampuan menggunakan herbisida KMCPA yang memiliki struktur aromatik yang stabil dan memiliki gugus klor yang toksik sebagai sumber karbon untuk pertumbuhan dan sumber energinya. Kemampuan tumbuh isolat bakteri pada herbisida KMCPA formula dikarenakan bakteri memiliki serangkaian enzim terutama enzim kunci dehalogenase. Enzim dehalogenase adalah enzim yang mengkatalisis pelepasan klor dari senyawa utamanya. Lepasnya halogen dari struktur utama herbisida KMCPA formula akan menghilangkan tingkat toksisitas herbisida tersebut. Hilangnya toksisitas KMCPA formula memungkinkan mikrobia khususnya bakteri isolat $\mathrm{M}$ menggunakan senyawa hasil biodegradasi KMCPA untuk pertumbuhan dan sumber energi. Proses pemecahan senyawa kloroaromatik juga melibatkan berbagai enzim lain seperti enzim yang bekerja untuk memutus gugus asetat dari $\mathrm{C} 1$. Biodegrasi senyawa aromatik yang komplek ini juga melibatkan enzim yang dapat mengakatalisis pemutusan gugus metil pada C2. Salah satu reaksi kunci dalam biodegradasi herbisida terhalogenasi ini adalah subtitusi klor pada atom C4 merupakan reaksi kunci yang dikatalisis enzim dehalogenase. Cincin aromatik yang terputus membentuk senyawa rantai karbon lurus menyebabkan mikrobia dapat menggunakan $\mathrm{C}$ sebagai sumber karbon dan energi. Jika reaksi berjalan sempurna dan lengkap maka dihasilkan produk akhir $\mathrm{CO}$, $\mathrm{H} 2 \mathrm{O}$ dan klorida.

Bertamabahnya biomassa isolat M pada kurva pertumbuhan merupakan indikasi bahwa herbisida KMCPA formula dapat digunakan sebagai sumber $\mathrm{C}$ pada metabolisme sel mikrobia. Sumber C dari herbisida KMCPA formula digunakan sebagai sumber energi dan akan dimetabolisme sempurna sehingga klorida yang ada akan dilepaskan sebagai gugus tunggal, disamping $\mathrm{CO} 2$ dan H2O. Kemampuan mengkatalisis lepasnya ion klorida dari KMCPA ini merupakan salah satu reaksi kunci pada proses biodegradasi senyawa kloroaromatik toksik melalui mekanisme dehalogenasi secara enzimatik. Dehalogenasi enzimatik dikatalisis oleh enzim dehalogenase yang dihasilkan oleh isolat $\mathrm{M}$. Berikut adalah kura kemampuan pertumbuhan isolat $M$ pada 3 macam konsentrasi herbisida KMCPA formula. 
Isolat bakteri $\mathrm{M}$ memiliki kemampuan tumbuh pada medium yang mengandung herbisida KMCPA formula dengan konsentrasi $1,1 \mathrm{~g} / \mathrm{L} ; 2,2$ $\mathrm{g} / \mathrm{L} ; 3,3 \mathrm{~g} / \mathrm{L}$ terlihat pada kurva pertumbahan biomassa berikut ini



Gambar 1. Pertumbuhan bakteri M pada 3 macam konsentrasi KMCPA formula

Pertambahan biomassa bakteri $\mathrm{M}$ pada subtrat utama sumber C KMCPA formula dengan dosis $1,1 \mathrm{~g} / \mathrm{L}$ mencapai fase logaritmik antara jam ke-6 sampai ke-27 demikian juga pada konsentrasi KMCPA formula 2,2 $\mathrm{g} / \mathrm{L}$ dan $3,3 \mathrm{~g} / \mathrm{L}$. Kemampuan bakteri isolat $\mathrm{M}$ tumbuh baik pada konsentrasi KMCPA formula 1,1g/L, 2,2 g/L maupun 3,3 $\mathrm{g} / \mathrm{L}$ karena isolat $\mathrm{M}$ memiliki kemampuan untuk memetabolisme KMCPA formula sebagai sumber C. Namun demikian dari kurva pertumbuhan dapat diketahui bahwa isolat bakteri $\mathrm{M}$ mengalami penurunan pertumbuhan pada konsentrasi KMCPA 2,2 g/L dan 3,3 g/L. Hal ini mengindikasikan bahwa dosis 2 kali dan 3 kali aplikasi di lapangan menyebabkan toksik bagi isolat bakteri M. Konsentrasi herbisida KMCPA formula $1,1 \mathrm{~g} / \mathrm{L}$ merupakan konsentrasi yang terbaik diantara 3 perlakuan. Konsentrasi 1,1 g/L adalah konsentrasi herbisida sesuai dosis aplikasi di lapangan. Dari hasil penelitian didapatkan bahwa konsentrasi herbisida KMCPA formula 1,1 $\mathrm{g} / \mathrm{L}$ merupakan konsentrasi sumber $\mathrm{C}$ yang terbaik untuk pertumbuhan bakteri isolat $\mathrm{M}$ dibanding konsentrasi 2,2 $\mathrm{g} / \mathrm{L}$ atau 3,3 $\mathrm{g} / \mathrm{L}$.

\section{KESIMPULAN :}

Bakteri isolat $\mathrm{M}$ merupakan isolat yang potensial karena memiliki ketahanan untuk tumbuh pada subtrat herbisida KMCPA formula 3,3 g/L yaitu 3 kali dosis lapangan.

\section{DAFTAR PUSTAKA}

Balajee, S \& Mahadevan, A. 1990. Utilization of chloroaromatic subtances by Azotobacter chroiococcum. Syst. Appl. Microbiol. 13. 194-198.

Commandeur \& Parsons, 1994. Degradation of halogenated aromatic compounds. Microbiol. Rev. 55, 59-79.

Don, R.H. \& J.M. Pemberton, 1981. Properties of six pesticide degradation plasmids isolated from Alcaligenes paradoxus and Alcaligenes eutrophus. J. Bacteriol. 145. 681-686.

Evans, W.C.; Smith B.S; W. Fernly, H. Davies, N; 1971. Bacterial metabolism of a gene cluster involvedin 3-chlorocatechol degradation. Proc. Nat. Acad. Sci. USA. 84. 4460-4464.

Haggblom, M.M.; 1992. Microbial breakdown of halogenated aromatric pesticides and realted compounds. FEMS Microbiology Reviews. 103. 29-72.

Jensen, 1960 in J.H. Slater, A.T Bull; D.J. Hardman; 1995. Genetics and Biochemnistry of dehalogenating enzymes. Ann. Rev. Microbiol. 48:163191.

Liu J.; Kurihata T.; Nardi-Tei V.; Okamura, T. Esaki N.; Soda, K.1995. Overexpression and feasible purification of thermostable L-2-haloacid dehalogenase of Pseudomonas sp YL. Biodegradation. 6. 223-227.

Loffler F, Muller R. \& Lingens F.; 1992. Purification and properties of 4halobenzoate-coenzyme A ligase from Pseudomonas sp. CBS3. Hoppe-Seyler's Zeitschrift fur Physiologische Chemie 373 : 1001-1007.

Loos, M.A.; 1975. Phenoxyalcanoic acids. In : Kearney, P.C. \& Kaufmann,PP. Herbicides : their Chemistry, Degradation and mode of Action 1.34-57. 
Nadeu L.J.; Fumin, M.; Breen, A.; sayler, G.S. 1994. Aerobic degradation of DDT by Alcaligenes eutrophus A5. Appl. Environ. Microbiol. 60, 51-53.

Peters, RA. 1952. Lethal synthesis. Proceedings of the Royal Society of London Series B. 139: 143-167.

Schmitz A. Gartemann K.H. Fieder J. Grund E. \& Eichenlaub R. 1991. Cloning and sequence analysis of genes for dehalogenating of 4-chlorobenzoate from Arthrobacter sp. Strain SU. Appl. Env. Microbiol. 58: 4068-4071.

Slater,J.H. Lovatt, D. \& Weightman, A.J. 1979. The growth of Pseudomonas putida PP3 on chlorinated aliphatic acids and its dehalogenase activity. Appl. Environ. Microbiol. 125, 144.

Slater, J.H.1994. Microbiol dehalogenation of haloaliphatic compounds In : Ratledge C.
Biochemistry of Microbiol Degradatin. pp. 379-421. Kluwer Academic Publ. Dordrecht. The Netherland.

Slater; J.H; Bull, A.T.; \& D.J. Hardman; 1995. Microbial Biodegradation 6. 181-189.

Soetarato, E.S. 1997. Uji kemampuan isolat bakteri tanah vulkanik untuk mendegradasi hidrokarbon terhalogenasi. Biologi. 2. 247-263.

Strotmann U. \& R. Roschenthaler, 1987. A Method for Screening of Bacteria : Aerobically degrading chlorinated shortchain hydrocarbon. Current. Microbiol. 15. 159-163. 